\title{
Oak pollen concentration in the air of selected Polish cities in 2020
}

\author{
Anna Rapiejko', Małgorzata Malkiewicz' ${ }^{2}$ Monika Ziemianin ${ }^{3}$, Aneta Sulborska ${ }^{4}$, Kazimiera Chłopek, \\ Grzegorz Siergiejko ${ }^{6}$, Ewa Kalinowska', Tomasz Wolski ${ }^{7}$, Kornel Szczygielski ${ }^{8}$, Agnieszka Lipiec ${ }^{9}$ \\ ${ }^{1}$ Allergen Research Center, Warsaw, Poland \\ ${ }^{2}$ Laboratory of Paleobotany, Department of Stratigraphical Geology, Insitute of Geological Sciences, \\ University of Wroclaw, Wroclaw, Poland \\ ${ }^{3}$ Department of Clinical and Environmental Allergology, Medical College, Jagiellonian University, Cracow, Poland \\ ${ }^{4}$ Department of Botany, University of Life Sciences in Lublin, Lublin, Poland \\ ${ }^{5}$ Faculty of Natural Sciences Institute of Earth Sciences, University of Silesia in Katowice, Poland \\ ${ }^{6}$ Pediatrics, Gastroenterology and Allergology Department, University Children Hospital, \\ Medical University of Bialystok, Bialystok, Poland \\ ${ }^{7}$ Institute of Marine \& Environmental Sciences, University of Szczecin, Szczecin, Poland \\ 8 Department of Otolaryngology with Division of Cranio-Maxillo-Facial Surgery in Military Institute of Medicine, \\ Warsaw, Poland \\ ${ }^{9}$ Department of Prevention of Environmental Hazards and Allergology, Medical University of Warsaw, \\ Warsaw, Poland
}

\begin{abstract}
:
The study aims to compare the oak pollen season in selected Polish cities: Bialystok, Bydgoszcz, Cracow, Katowice, Piotrkow Trybunalski, Lublin, Olsztyn, Opole, Szczecin, Warsaw, and Wroclaw in 2020. Measurements were made using the volumetric method, with a Hirst-type sampler. Oak pollen season, defined as the period with $98 \%$ of the annual total catch, started between April 14 $4^{\text {th }}$ (in Opole) and April 25 $5^{\text {th }}$ (in Lublin). The season ended on June $1^{\text {st }}$ at the latest; in Sosnowiec, Bydgoszcz, Olsztyn, and Bialystok. It lasted from 30 to 47 days (37 days on average). The maximum daily oak pollen concentrations were observed between April 24 ${ }^{\text {th }}$ and May $11^{\text {th }}$. The highest annual sum of oak pollen grains (SPI) was recorded in Lublin, while the lowest in Bialystok. The highest concentrations of 596 oak pollen grains $/ \mathrm{m}^{3}$ were noted in Lublin on April 28 $8^{\text {th }}$. The longest exposure to high concentrations of oak pollen (> 91 grains $/ \mathrm{m}^{3}$ ), lasting 12-13 days, was recorded in Lublin, Opole, and Wroclaw.
\end{abstract}

Key words: pollen concentration, oak (Quercus), allergens

\section{Introduction}

The genus Quercus, belonging to the Fagaceae family, includes 600 species found almost exclusively in the northern hemisphere; mainly in the temperate climate zone [1]. Oak trees grow abundantly in Europe and contribute to pollen concentration in spring [2].

In Poland, two species and the hybrids are found wild. The most common, growing throughout the country in deciduous and mixed forests and the mountains up to $700 \mathrm{~m}$ above sea level, is pedunculate oak (Quercus robur L.). Sessile oak, (Quercus petraea [Matt.] Liebl) occurs less frequently, mostly in the lowlands, while in north-eastern Poland it does not grow at all. Pubescent oak (Quercus pubescens Willd.), which grows on the slopes of the Odra valley in the Bielinek nature reserve, is sometimes mentioned as the third 
wild-growing species in Poland $[1,3]$. A dozen alien species are planted in parks and gardens.

The clinical significance of oak pollen in pollinosis is considered to be moderate $[4,5]$. European Academy of Allergy and Clinical Immunology in Global Atlas of Allergy lists major oak pollen allergen, Que a 1 as one of eight major tree allergens within Bet v 1-related proteins [6]. The presence of homologous allergens is responsible for IgE cross-reactivity among Fagales pollen (birch, hazel, alder, beech, oak, and hornbeam) and with various fruits and vegetables, a condition known as oral allergy syndrome $[7,8]$.

\section{Aim}

This study aims to compare the oak pollen season in selected Polish cities: Bialystok, Bydgoszcz, Cracow, Katowice, Piotrkow Trybunalski, Lublin, Olsztyn, Opole, Szczecin, Warsaw and Wroclaw in 2020

\section{Material and method}

Pollen measurements were performed using the volumetric method, with a Hirst-type sampler operating in a continuous volumetric mode. Counts were recorded over 7-day cycles and analyzed separately for each 24-hour period.

The analysis was based on the following variables:

- duration of the pollen season, determined by the 98\% method, where the beginning and the end of the season fell on days with $1 \%$ and $99 \%$ of the annual total pollen catch, respectively [9]

- sum of the daily average pollen concentrations over the season expressed by the SPI (seasonal pollen integral) [10]

- maximum daily pollen concentration in the season and peak date

- the number of days with above-threshold pollen level, which was adopted according to the litera- ture. According to Burge [11], the threshold level of oak pollen concentration in the air, causing the initial symptoms of inhalant allergy in sensitized individuals, is 16 pollen grains per $1 \mathrm{~m}^{3}$ of air. While the level of high pollen concentration, at which symptoms are present in most individuals allergic to oak allergens, is 91 grains per $1 \mathrm{~m}^{3}$ of air.

\section{Results and discussion}

In 2020 , the oak pollen season began between April $14^{\text {th }}$ and $25^{\text {th }}$ and lasted until the third decade of May or even the beginning of June (tab. 1). It started on April $14^{\text {th }}$ at the earliest in Opole and on April $16^{\text {th }}$ in Wroclaw and Sosnowiec, and on April $25^{\text {th }}$ at the latest in Lublin (tab. 1, fig. 1-3). In Lublin, Warsaw, Piotrkow Trybunalski, and Wroclaw the onset of the season occurred on dates similar to the previous year, in Bialystok, Bydgoszcz, and Sosnowiec; 6-7 days later than in 2019, while in Szczecin even 18 days later than in 2019 (tab. 1) [12]. The year 2020 is in line with the tendency to delay the beginning of the oak pollen season in Szczecin observed over many years by Puc [13]. In 2017, the oak pollination season began in Szczecin on April 1 $1^{\text {st }}$, in 2018 on April 17 $7^{\text {th }}$, while in 2020 on April $24^{\text {th }}[13,14]$.

The average length of the pollination season in 2020 was 37 days. It was between the values for 2017 (44 days) and 2018 and 2019 (33 days) [12-14]. There was a marked variation in duration between monitoring sites. The shortest season was recorded in Piotrkow Trybunalski (30 days), while the longest in Sosnowiec (47 days) (tab. 1, fig. 2, 5). Analyzing oak pollen seasonality and severity across Europe, Grundströma et al. [15] noticed that the length of the oak pollen season varied significantly between analyzed sites across Europe. Long seasons, exceeding 50 days, were recorded at southern and non-coastal sites (Badajoz, Lyon, Worcester, Leicester), while shorter ones at northern and coastal areas (Leiden, Malmo,

Table 1. Characteristics of oak pollen season in 2020.

\begin{tabular}{|c|c|c|c|c|c|c|c|c|c|c|c|}
\hline Features of pollen season & Bialystok & Bydgoszcz & Cracow & $\begin{array}{l}\text { Piotrkow } \\
\text { Trybunalski }\end{array}$ & Lublin & Olszlyn & Opole & $\begin{array}{l}\text { Sosno- } \\
\text { wiec }\end{array}$ & Szozecin & Warsaw & Wroclaw \\
\hline $\begin{array}{l}\text { Duration of pollen season } \\
\text { (number of days) }\end{array}$ & $\begin{array}{l}23 \text { IV- } \\
1 \mathrm{VI} \\
(39)\end{array}$ & $\begin{array}{l}24 \text { IV- } \\
1 \mathrm{VI} \\
(38)\end{array}$ & $\begin{array}{l}18 \text { IV- } \\
28 \mathrm{~V} \\
(36)\end{array}$ & $\begin{array}{l}24 \text { IV- } \\
23 \mathrm{~V} \\
(30)\end{array}$ & $\begin{array}{l}25 \text { IV- } \\
31 \mathrm{~V} \\
(37)\end{array}$ & $\begin{array}{l}22 \text { IV- } \\
1 \mathrm{VI} \\
(41)\end{array}$ & $\begin{array}{l}14 \text { IV- } \\
23 \mathrm{~V} \\
(40)\end{array}$ & $\begin{array}{l}16 \text { IV- } \\
1 \mathrm{VI} \\
(47)\end{array}$ & $\begin{array}{l}24 \text { IV- } \\
27 \mathrm{~V} \\
(34)\end{array}$ & $\begin{array}{l}23 \text { IV- } \\
24 \mathrm{~V} \\
(32)\end{array}$ & $\begin{array}{l}16 \text { IV- } \\
21 \mathrm{~V} \\
(36)\end{array}$ \\
\hline Seasonal pollen integral & 184 & 1143 & 1279 & 2238 & 4545 & 549 & 3499 & 1228 & 913 & 2290 & 2976 \\
\hline Peak value and peak date & $\begin{array}{l}30 \\
(5 \mathrm{~V})\end{array}$ & $\begin{array}{l}98 \\
(8 \mathrm{~V}, 11 \mathrm{~V})\end{array}$ & $\begin{array}{l}94 \\
(25 \mathrm{IV})\end{array}$ & $\begin{array}{l}211 \\
(11 \mathrm{~V})\end{array}$ & $\begin{array}{l}596 \\
(28 \mathrm{IV})\end{array}$ & $\begin{array}{l}45 \\
(5 \mathrm{~V})\end{array}$ & $\begin{array}{l}378 \\
(28 \mathrm{IV})\end{array}$ & $\begin{array}{l}147 \\
(11 \mathrm{~V})\end{array}$ & $\begin{array}{l}85 \\
(9 \mathrm{~V})\end{array}$ & $\begin{array}{l}324 \\
(11 \mathrm{~V})\end{array}$ & $\begin{array}{l}336 \\
(24 \text { IV) }\end{array}$ \\
\hline Days $\geq 16$ grains $/ \mathrm{m}^{3}$ & 2 & 22 & 29 & 28 & 31 & 12 & 32 & 20 & 20 & 26 & 31 \\
\hline Days $\geq 91$ grains $/ \mathrm{m}^{3}$ & 0 & 2 & 1 & 6 & 13 & 0 & 12 & 2 & 0 & 8 & 12 \\
\hline
\end{tabular}


Figure 1. Oak pollen concentration in the air of Lublin in 2020.

700,00

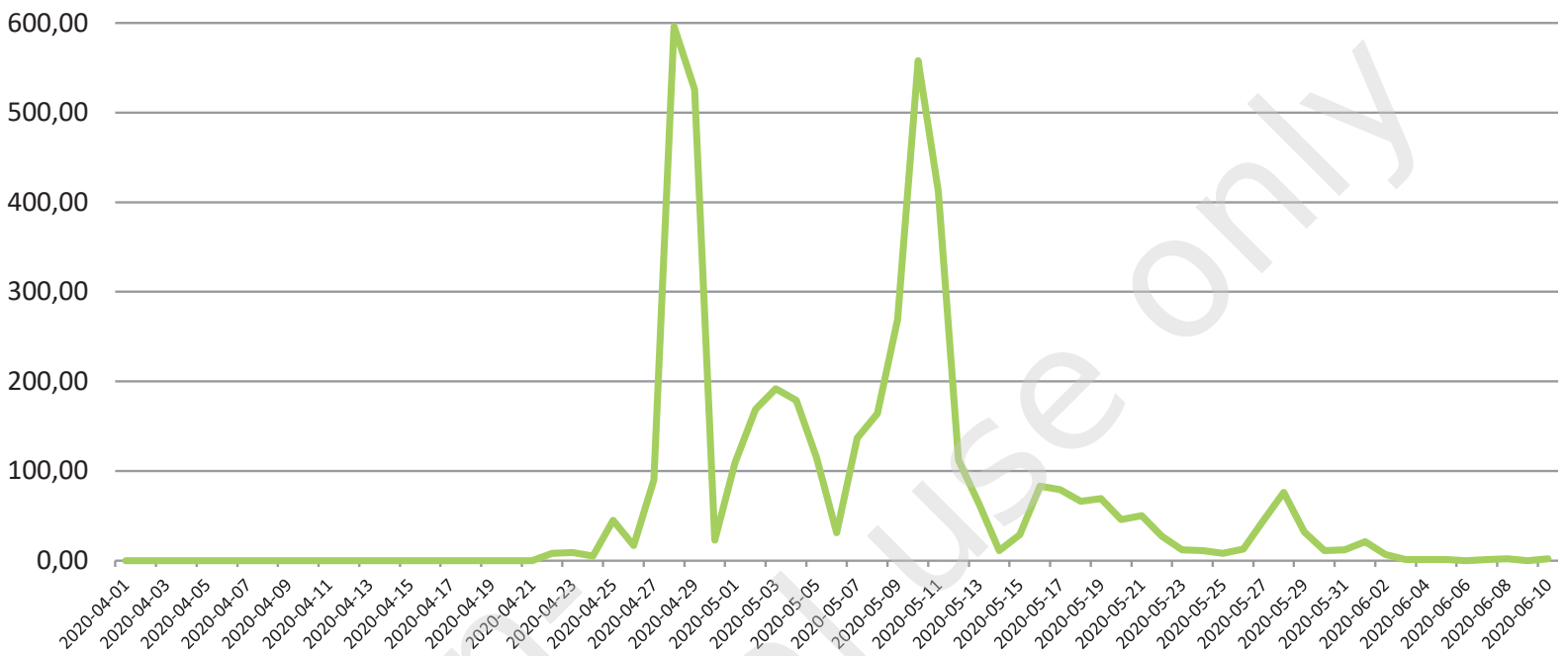

Figure 2. Oak pollen concentration in the air of Cracow and Sosnowiec in 2020.

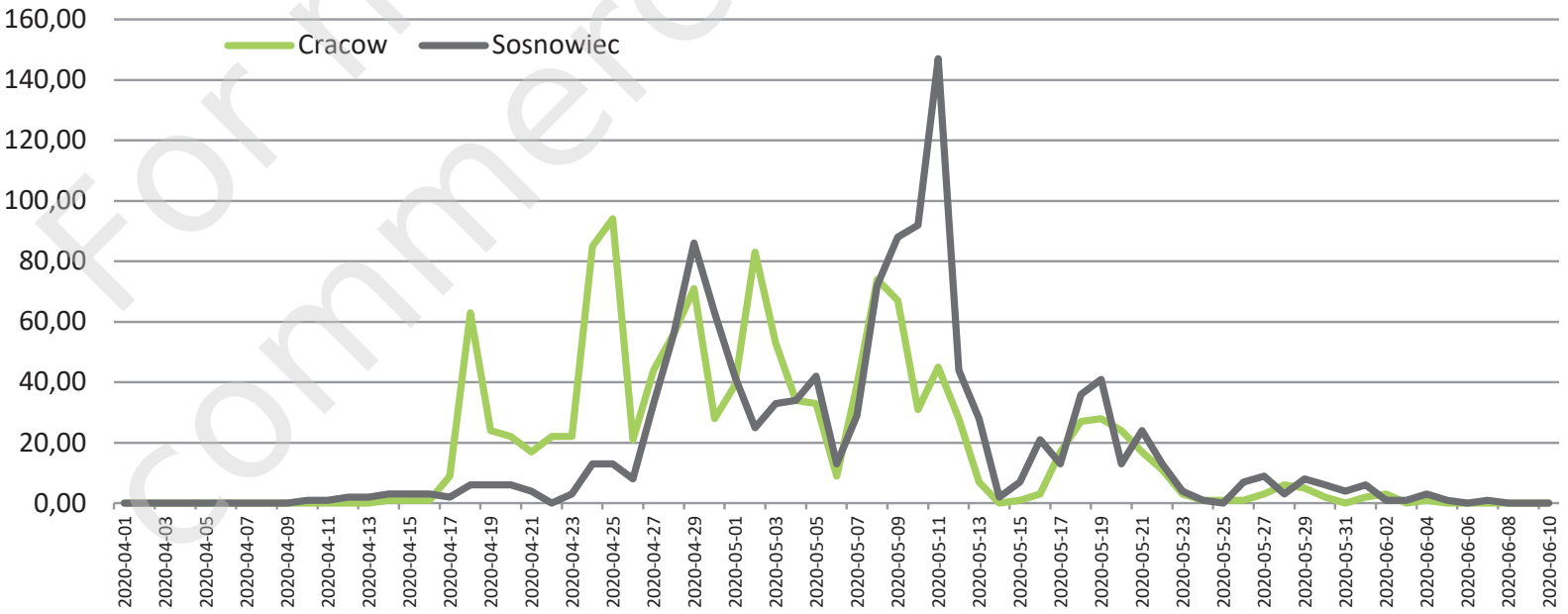

Figure 3. Oak pollen concentration in the air of Wroclaw and Opole in 2020.

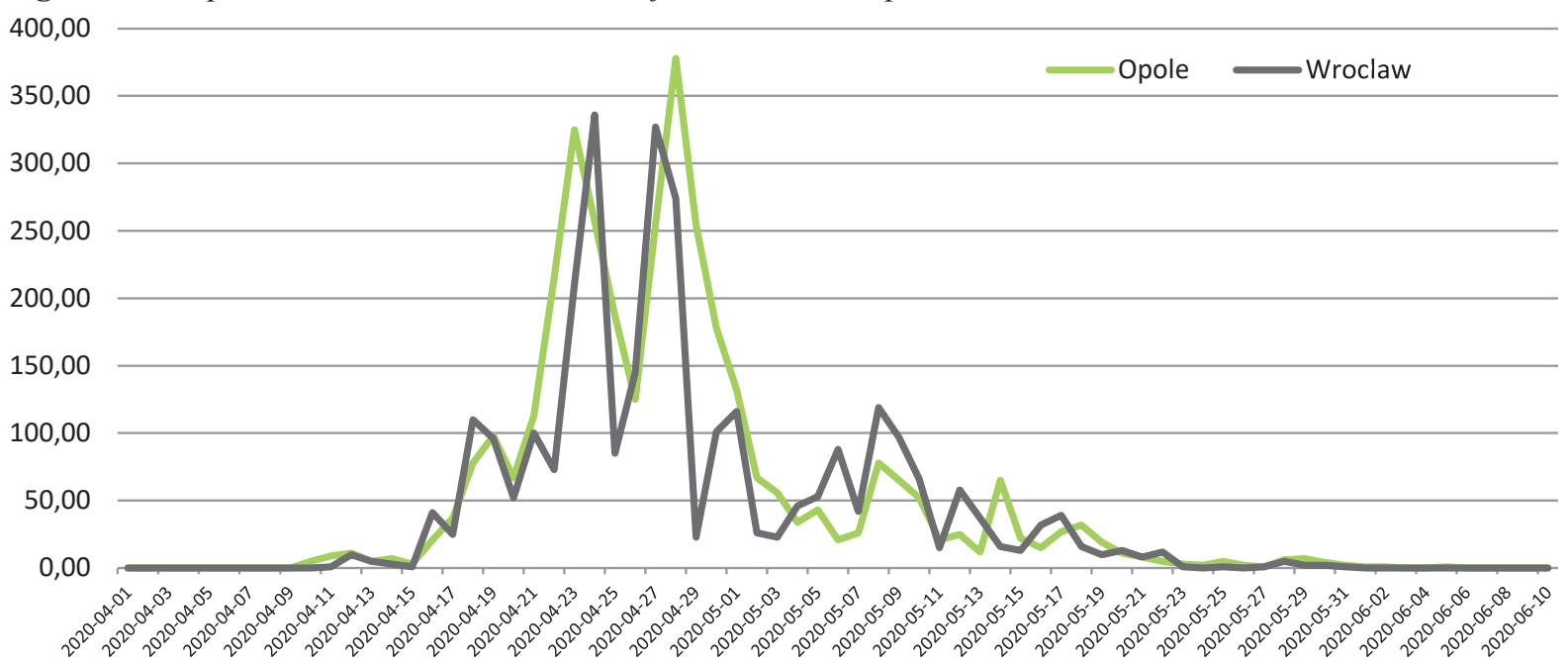


Figure 4. Oak pollen concentration in the air of Szczecin and Warsaw in 2020.

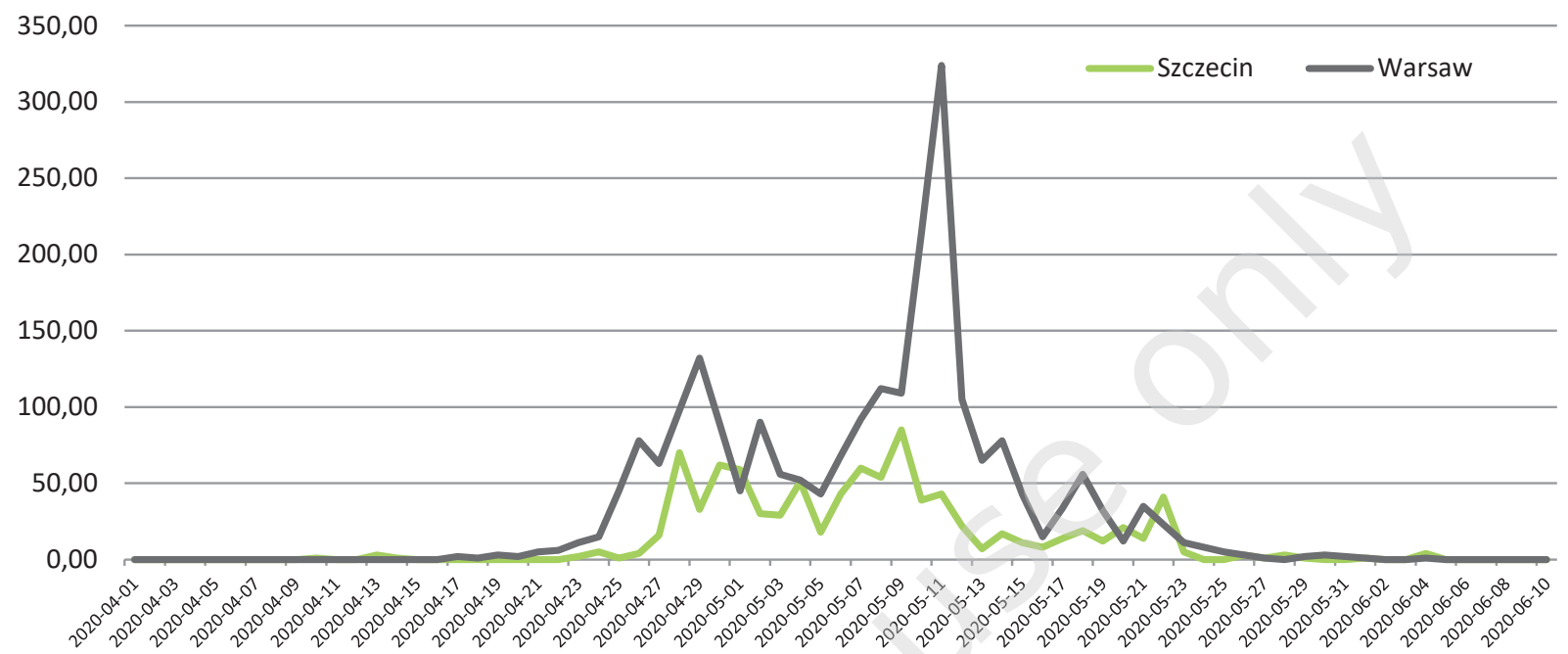

Figure 5. Oak pollen concentration in the air of Piotrkow Trybunalski and Bydgoszcz in 2020.

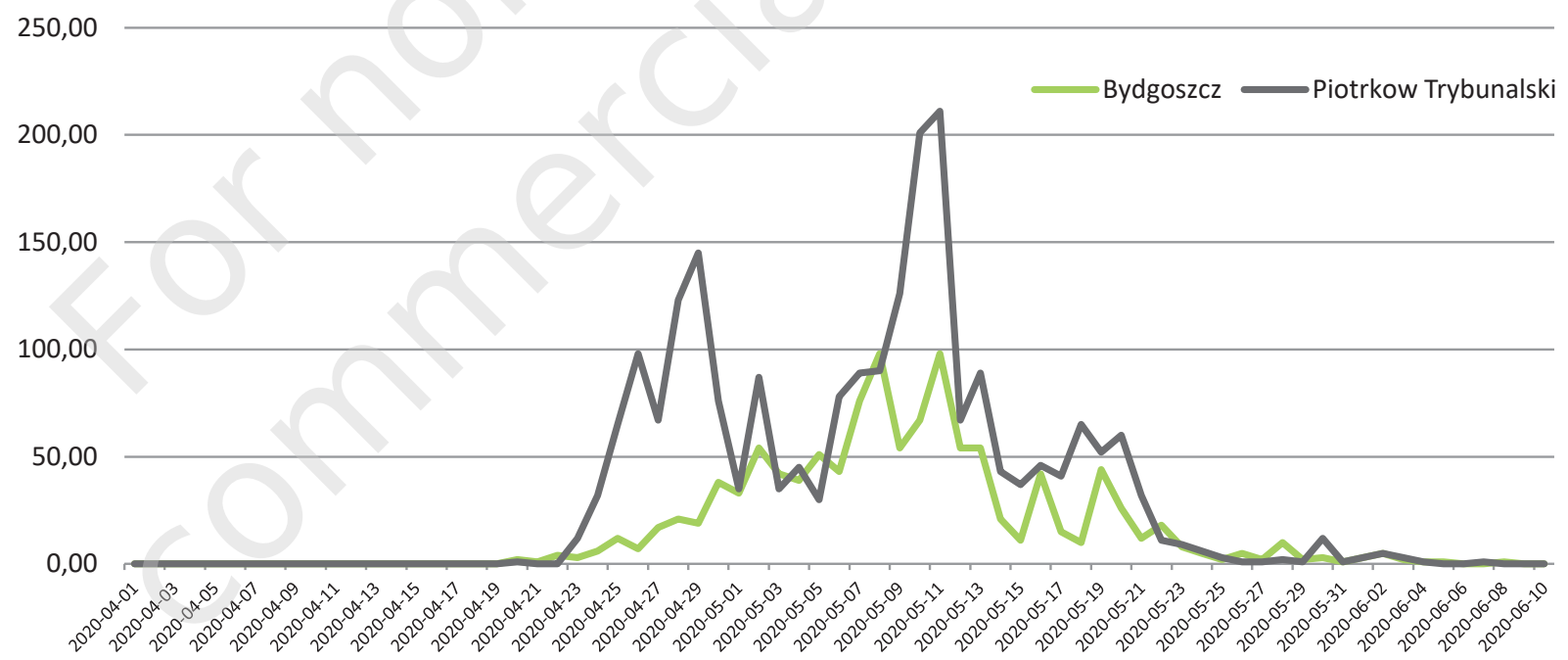

Figure 6. Oak pollen concentration in the air of Bialystok and Olsztyn in 2020.

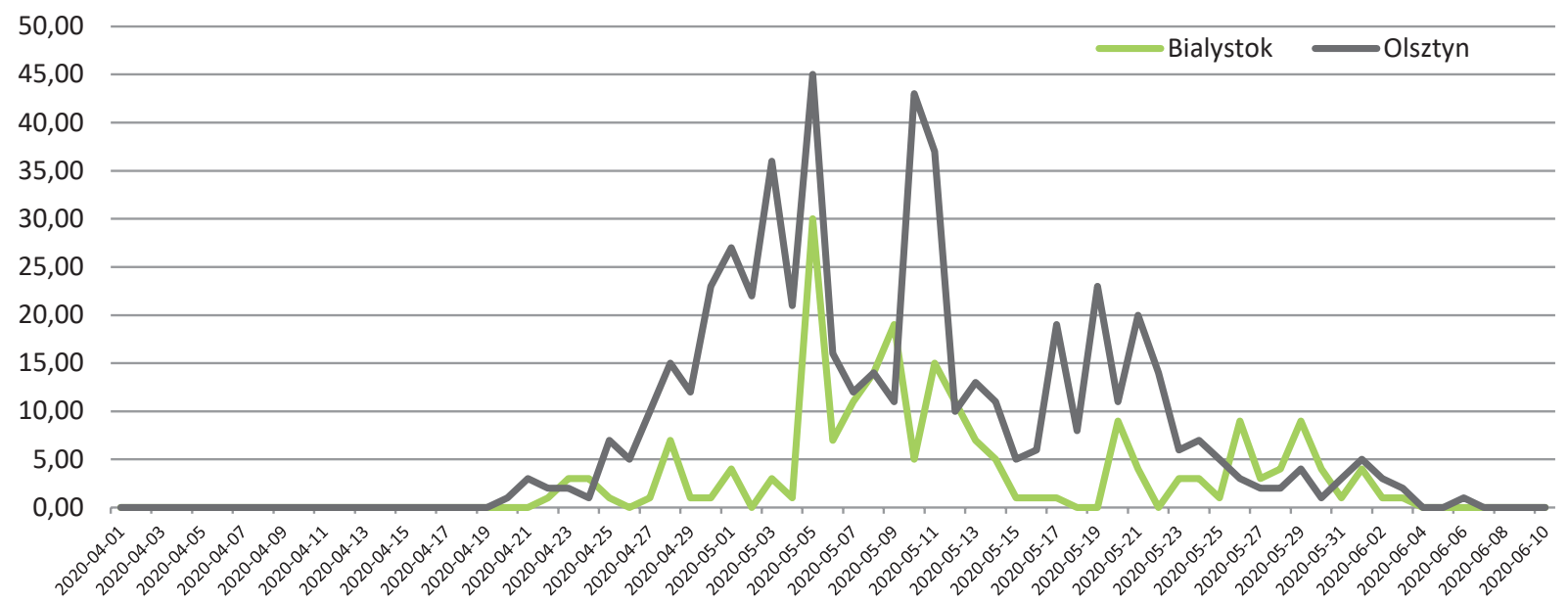


Copenhagen, Viborg, and Goteborg) [15]. More oak species with different flowering times may contribute to the length of pollen season.

The highest annual sum of oak pollen grains (SPI) was recorded in Lublin, while the lowest in Bialystok (tab. 1). The average SPI for the oak pollen season in 2020 was 1895 . It was similar to the level in 2018 (1816) and higher than in 2017 (1363) and 2019 [12-14].

The highest daily pollen concentration was noted in Lublin (596 grains $/ \mathrm{m}^{3}$ on April $28^{\text {th }}$ ), followed by records in Opole (378 grains $/ \mathrm{m}^{3}$ on the same day) and Wroclaw (336 grains $/ \mathrm{m}^{3}$ on April $24^{\text {th }}$ ) (tab. 1). The maximum daily pollen concentration in 2020 (reached in Lublin) exceeded over 2 times the level reached in 2019. For all analyzed sites these were much higher values than those recorded in 2019 (tab. 1) [12]. The maximum daily concentrations in the analyzed monitoring sites were recorded between April $24^{\text {th }}$ and May $11^{\text {th }}$ (tab. 1). As in previous years, the curves illustrating the oak pollen season are characterized by more than one peak, which is related to the different time of flowering of different oak taxa [12-14].

The longest exposure to high concentrations of oak pollen (91 grains $/ \mathrm{m}^{3}$ and above), lasting 12-13 days, was recorded in Lublin, Opole, and Wroclaw. In Warsaw and Piotrkow Trybunalski, the highest risk of oak pollen allergens lasted 8 and 6 days, respectively, while in Szczecin, Bialystok and Olsztyn oak pollen concentration did not reach the level of 91 grains $/ \mathrm{m}^{3}$ at all (tab. 1). In 2019, the longest intense exposure to oak pollen allergens was also recorded in Lublin, but it did not exceed 7 days and in 5 analyzed cites the level of 91 grains $/ \mathrm{m}^{3}$ was not reached at all [12].

\section{Conclusions}

The oak pollen season in 2020 began between mid-April in Opole, Wroclaw, and Sosnowiec; and last days of April in Lublin. It lasted from 30 to 47 days, depending on the monitoring site (37 days on average).

The highest concentrations of oak pollen were recorded in Lublin, Opole, Wroclaw, Warsaw, and Piotrkow Trybunalski, whereas the lowest, in Bialystok. The longest exposure to high concentrations of oak pollen, lasting 12-13 days, was recorded in Lublin, Opole, and Wroclaw.

The oak pollen season in 2020, compared to the season in 2019, was characterized by longer average pollen season, the higher average sum of daily concentrations over the season (SPI), higher maximum daily concentrations, and longer exposure to high concentrations of oak pollen in the majority of investigated sites.

\section{References}

1. Seneta W, Dolatowski J. Dendrologia. Wydawnictwo Naukowe PWN, Warszawa 2009.

2. Skjøth CA, Šikoparija B, Jäger S. EAN-Network. Pollen sources. Allergenic Pollen. Springer Netherlands, Dordrecht 2013: 9-27.

3. Bugała W. Drzewa i krzewy. Państwowe Wydawnictwo Rolnicze i Leśne, Warszawa 2000

4. Egger $C$, Focke $M$, Bircher AJ et al. The allergen profile of beech and oak pollen. Clin Exp Allergy. 2008; 38: 1688-96.

5. Rapiejko P, Lipiec A, Jurkiewicz D. Alergogenne znaczenie pytku dębu. Alergia. 2004; 2: 38-41.

6. Ferreira F, Gadermaier G, Wallner M. Tree pollen allergens. Global Atlas of Allergy 2014: 18-21.

7. Breiteneder H, Kleine-Tebbe J. PR-10-like allergens. In: Maticardi PM, Kleine-Tebbe J, Hoffmann HJ et al. EAACI Molecular Allergology. User's Guide 2016: 299-309.

8. Scala E, Asero R, Niederberger V. Tree pollen allergens. In: Maticardi PM, Kleine-Tebbe J, Hoffmann HJ et al. EAACI Molecular Allergology. User's Guide 2016: 71-83.

9. Emberlin J, Savage M, Jones S. Annual variations in grass pollen seasons in London 1961-1990: trends and forecast models. Clin Exp Allergy. 1993; 23(11): 911-8.

10. Galan $C$, Artaitti A, Bonnini $M$ et al. Recommended terminology for aerobiological studies. Aerobiologia. 2017: 293-5. http://doi.org/10.1007/s10453-017-9496-0.

11. Burge HA. Monitoring for airborne allergens. Ann Allergy. 1992; 9: 9-21.

12. Dąbrowska-Zapart K, Chtopek K, Malkiewicz M et al. Oak pollen season in selected cities of Poland in 2019. Alergoprofil. 2019; 15(2): 12-6.

13. Puc M, Myszkowska D, Chtopek Ket al. Oak pollen in the air of Poland in 2017. Alergoprofil. 2017; 13(3): 124-8.

14. Sulborska A, Weryszko-Chmielewska E, Piotrowska-Weryszko $K$ et al. The oak pollen concentration in the air of selected cities in Poland in 2018. Alergoprofil. 2018; 14(3): 67-71.

15. Grundströma M, Adams-Groom B, Pashley CH et al. Oak pollen seasonality and severity across Europe and modeling the season start using a generalized phenological model. Sci Total Environ. 2019; 663: 527-36.

ORCID

A. Rapiejko - ID - orcid.org/0000-0002-8906-2405

M. Malkiewicz - ID - orcid.org/0000-0001-6768-7968

M. Ziemianin - ID - orcid.org/0000-0003-4568-8710

G. Siergiejko - ID - orcid.org/0000-0003-4084-8332

E. Kalinowska - ID - orcid.org/ 0000-0003-4821-6882

T. Wolski - ID - orcid.org/0000-0002-1368-6107

K. Szczygielski - ID - orcid.org/0000-0002-3717-5424

A. Lipiec - ID - orcid.org/0000-0003-3037-2326 
Author's contributions:

A. Rapiejko: 55\%; other Authors: 5\% each.

Conflict of interests:

The authors declare that they have no competing interests.

Ethics:

The contents presented in this paper are compatible with the rules of the Declaration of Helsinki, EU directives, and standardized requirements for medical journals.

Research in Bialystok, Bydgoszcz, Piotrkow Trybunalski, Olsztyn, Opole, Warsaw funded by Allergen Research Center Ltd. (Ośrodek Badania Alergenów Środowiskowych Sp. z 0.0.). Financial support:

None.

Copyright: (C) Medical Education sp. z 0.0. This is an Open Access article distributed under the terms of the Attribution-NonCommercial 4.0 International (CC BY-NC 4.0). License (https://creativecommons.org/licenses/by-nc/4.0/), allowing third parties to copy and re- distribute the material in any medium or format and to remix, transform, and build upon the material, provided the original work is properly cited and states its license.

\section{Correspondence}

Assistant professor Agnieszka Lipiec, MD, PhD

Department of Prevention of Environmental Hazards and Allergology,

Medical University of Warsaw

02-091 Warsaw, Żwirki i Wigury 61

e-mail: alipiec@wum.edu.pl 